\title{
FACTORS AFFECTING HOUSEHOLD FOOD EXPENDITURE THROUGH THE UTILIZATION OF YARD LAND IN DEWANTARA SUBDISTRICT, ACEH UTARA
}

\author{
Martina $^{1}$, Riyandhi Praza ${ }^{2}$, and Zuriani ${ }^{3}$ \\ ${ }^{1}$ Universitas Malikussaleh \\ ${ }^{2}$ Universitas Malikussaleh \\ ${ }^{3}$ Universitas Malikussaleh
}

Correspondence Adress: Jalan Cot Teuku Nie-Reuleut Kecamatan Muara Batu, Aceh Utara Email : ${ }^{1}$ martina@ unimal.ac.id, ${ }^{2}$ riyandhi.praza@ unimal.ac.id, ${ }^{3}$ zuriani@ unimal.ac.id

\begin{abstract}
Food is a basic need that must be met by households. Utilization of home yard land is one of the alternatives to realize food self-sufficiency in households in Dewantara District which iscan save on food expenditure and ensure the fulfillment of household food needs which are always available, easily accessible and can be used at any time. This study aims to analyze the factors that influence household food expenditures that utilize yard land with horticultural cultivation in Dewantara Subdistrict, Aceh Utara. The sample in this study was 60 families who were selected by simple random sampling. Data were analyzed descriptively quantitatively using multiple linear regression test. The results showed that simultaneously the factorIncome $\left(X_{1}\right)$, yard area $\left(X_{2}\right)$, number of household members $\left(X_{3}\right)$, housewife education $\left(X_{4}\right)$, and number of working household members $\left(X_{5}\right)$ have a significant effect on food expenditure. Partially, only the income factor $\left(X_{1}\right)$ and the number of household members $\left(X_{3}\right)$ have a significant effect on household food expenditure.
\end{abstract}

Keywords: Effect, Food Expenditure, Multiple Linear Regression

\section{INTRODUCTION}

Indonesia has the potential to improve the agricultural sector. However, the availability of land and natural resources is not matched by the availability of adequate agricultural products (Martina, Shamadiyah, and Praza 2018)The population in Indonesia from year to year continues to grow. This increase is directly followed by an increase in the need for food. However, efforts to fulfill these foodstuffs are getting more and more obstacles, including the phenomenon of global climate change, a decrease in land area and productivity, as well as the increasing number of cases of pests and plant diseases causing a decrease in crop yields. Therefore, new strategies to increase food sufficiency, security and self-sufficiency need to be developed immediately (Djufry 2012). One of the new strategies to increase food sufficiency, security, and self-sufficiency is the use of yards.

Utilization of the yard around the house can provide additional results in the form of food ingredients such as secondary crops, fruits, vegetables, flowers, spices, medicines, wood, craft materials, livestock, fish, compost and bee honey (Ashari, Saptana, and Purwantini 2016). The use of yard land is not only done once but is carried out continuously.

The Agricultural Extension Center, Dewantara Sub-district, Aceh Utara, implements a program to use home yard land as an alternative to realize food self-sufficiency in the household. The important objectives to be achieved in the development of this yard land use program include: (1) improving family skills, (2) meeting the food and nutritional needs of families and communities in a sustainable manner, (3) developing productive economic activities for families, (4) creating an environment clean and healthy green independently.

The use of yard land is carried out to maximize the use of land as a medium for planting commodities that can be used to meet the daily needs of the community. The area of the yard in 


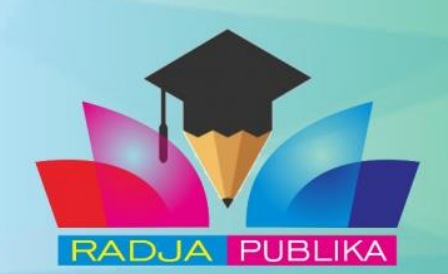

Volume 1 No. 1 (2021)

Dewantara sub-district is 1,050 hectares (BPP Dewantara, 2020) which is used by the community for cultivating horticultural commodities in the form of vegetables, kitchen spices, fruits and ornamental plants. In addition to being consumed, these commodities can also be sold to increase household income which is used to meet household food needs.

The use of the yard is generally carried out by housewives who have an important role in meeting household food needs. Through the use of yards with horticultural cultivation, you can save on food expenditure and ensure the fulfillment of household food needs which are always available, easily accessible and can be used at any time. according to(Yudaningrum 2011), Income is also an important factor in determining household expenditure. If income increases, consumption patterns will be more diverse, consumption of food with high nutritional value will also increase so that food expenditure will also increase. Based on this description, the purpose of this study is to analyze the factors that influence household food expenditures that utilize yard land with horticultural cultivation in Dewantara Subdistrict, Aceh Utara.

\section{LITERATURE REVIEW}

\subsection{Yard Land}

The yard is a plot of land around the house that is easy to cultivate with the aim of increasing the fulfillment of micronutrients through improving the family menu. The yard is also often referred to as a living barn, a living shop or a living pharmacy. Under certain conditions, the yard can take advantage of the garden/swamp around the house(Yulida 2012)

The yard has a number of roles in the socio-economic life of the farmer's household. according toAshari et al., (2016), The yard is often called a living barn, a living shop or a living pharmacy. It is called a living barn because from time to time basic food needs such as corn, tubers and so on are available in the yard. These materials are stored in the yard alive. It is called a live shop, because in the yard there are vegetables that are useful for meeting family consumption needs, where some households have to buy them with cash. Meanwhile, it is called a live pharmacy because the yard is planted with various medicinal plants which are very useful in curing diseases traditionally. The yard is an open land that can be used and has a very important meaning for people's lives. No matter how narrow the yard,

Horticultural commodity is a commodity that can be cultivated in the yard. Horticulture comes from the Latin "hortus" (garden plant) and cultura / colere" (cultivation), so it can be interpreted as a plant that is cultivated around the house or garden. The word "horticulture" is now often used to refer to several types of plants that can be cultivated. So the process includes seeding, tissue culture, harvesting, packaging and distribution. Horticultural systems are often used in modern agricultural processes (Zulkarnain, 2009).

\subsection{Factors Affecting Household Food Expenditure}

Several factors that influence food expenditure of poor households include:

\section{1) Household Income}

Household income is the amount of real income of all household members that is used to fulfill together in the household (Reksoprayitno, 2013). The limited nature of family resources or available income will affect the priority of family expenditure allocation.

\section{2) Education Level of Housewives}

Higher education will increase the awareness of a housewife to seek as much information as possible in an effort to improve the welfare of her family, including information about food and nutritional knowledge. On the other hand, housewives with low education, the average nutritional knowledge of these housewives is also low. The higher the education of a housewife, the smaller the percentage of expenditure on food(Arida, Sofyan, and Fadhiela 2015)

\section{3) Number of Household Members}

The number of household members will affect consumption. Households with a larger number of household members tend to have high levels of consumption. The number of household members determines to a certain extent the amount of food consumed, the composition of the contents of the food 
basket, the size of the space in the house where you live, spending on clothing, education, health and recreation.(Yanti and Murtala 2019)

\section{4) The area of the yard}

Land for farmers is a very important production factor. Land is a source of income for survival. The area of land ownership and control is one of the main factors that determine the level of income that affects the amount of expenditure in a farmer's household. The wider the farmer's land, the higher the production so that the income is also high. Yard land can be used as a potential food provider for families, basically it is a form of increasing community participation in realizing food security(Ratna and Gustiani 2016).

\section{5) Number of working household members}

The decision to work is a fundamental decision about how to spend time (Sumarsono, 2009). The decision to work in the job market is not only determined by individual decisions. In a household a person's decision to work can be influenced by other family members. Family members are involved in work due to large household expenses. Household expenditure is expenditure that must be spent to meet household consumption.

\section{IMPLEMENTATION METHOD}

This research was conducted in Dewantara District, North Aceh Regency. The population in this study were all households that used their yards with horticultural cultivation to meet food needs in Dewantara District, amounting to 585 families (BPP Dewantara, 2020). The sample in this study was taken as many as 60 families in accordance with Arikunto's opinion (2013), if the population is large or more than 100 people can be taken $10-15 \%$ or $20-25 \%$ or more. The sampling method uses a simple random sampling technique, which is a sampling technique from population members that is carried out randomly without regard to the strata that exist in the population (Sugiono, 2017).

The types of data used in this study are primary data and secondary datawhich was processed using statistical test dwith multiple linear regression analysis model. The analysis model is as follows

$\mathrm{Y}=\alpha+\beta_{1} \mathrm{X}_{1}+\beta_{2} \mathrm{X}_{2}+\beta_{3} \mathrm{X}_{3}+\beta_{4} \mathrm{X}_{4}+\beta_{5} \mathrm{X}_{5}+\mathrm{e}$

Where :

$\mathrm{Y} \quad$ : Household food expenditure (Rp/month)

$\beta_{1}-\beta_{5} \quad$ : Regression coefficient

Testwhat is done is the classical assumption test and statistical test. Classical assumption test consists of normality test, multicollinearity test and heteroscedasticity test. Statistical tests were carried out using the $\mathrm{F}$ test, $\mathrm{t}$ test, and $\mathrm{R}^{2}$. The $\mathrm{F}$ test is used to determine the simultaneous (simultaneous) significance of the model on the variables studied and the $t$ test is used to determine the partial significance of each of the variables studied, while the $\mathrm{R}$ test ${ }^{2}$ to find out how much variation of the independent variable is able to explain the dependent variable.

\section{RESULTS AND DISCUSSION}

\section{Factors Affecting Household Food Expenditure Through The Utilization Of Yard Land In} Dewantara Subdistrict, Aceh Utara

\subsection{Classic assumption test}

Deviation test against classical assumptions can be done through normality test, multicollinearity test and heteroscedasticity test:

\subsubsection{Data Normality Test}

The normality test is a test of the normality of the data distribution. To find out the normality test, it can be seen on the Normal PP Plot og Regression curve. The meaning of normally distributed data is that the data will follow the form of a normal distribution. If the data spreads around the diagonal line and follows the direction of the diagonal line or the histogram graph shows a normal distribution 
pattern, then the regression model meets the assumption of normality. Conversely, if the data spreads

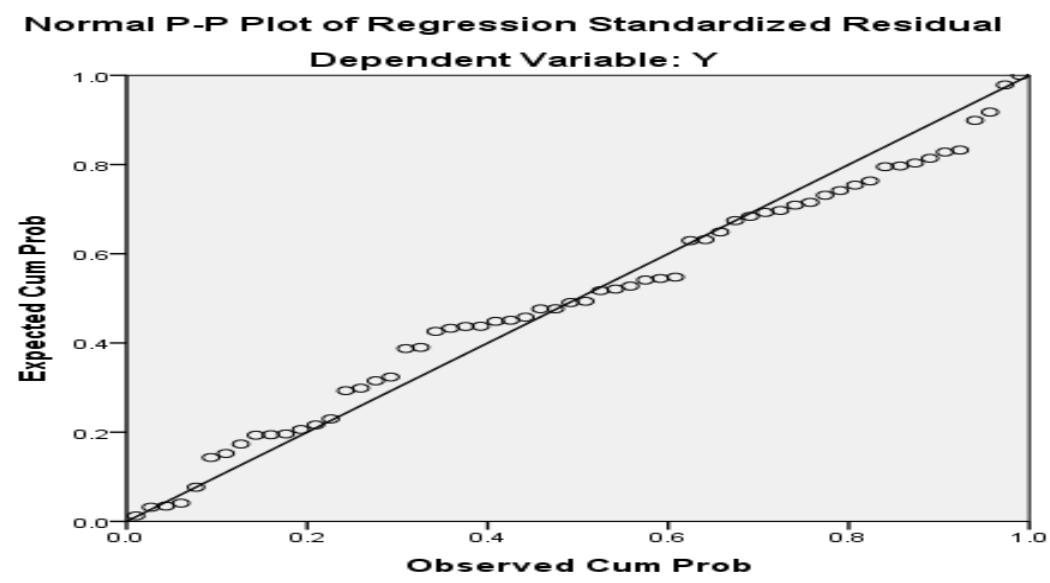

far from the diagonal line or does not follow the direction of the diagonal line or the histogram graph does not show a normal distribution pattern, then the regression model does not meet the assumption of normality. Based on the results of the data obtained that the output data in the multiple linear regression model, the dependent variable (dependent) and the independent variable (Independent) have a normal distribution, because the data spread on the normal P-P Plot Regression Standardized Residual graph follows the normal line as shown in Figure 1 below :

Figure 1. Normal Graph Plot

\subsubsection{Multicollinearity Test}

The multicollinearity test aims to test whether the regression model found a correlation between the independent variable and the dependent variable. A good regression model should not have a correlation between these variables. To detect the presence of multicollinearity, it can be seen from the Value Inflation Factor (VIF). If the VIF value is $>10$, then multicollinearity occurs, on the contrary, if VIF $<10$, then there is no multicollinearity (Widarjono, 2018). From the results of multiple linear regression analysis, it can be seen that the VIF values for all independent variables are shown in table 5 below:

Table 1. Multicollinearity Test Results

\begin{tabular}{lrrl}
\hline \multirow{2}{*}{ Variable } & \multicolumn{2}{c}{ Collinearity Statistics } & \multirow{2}{*}{ Information } \\
\cline { 2 - 3 } & Tolerance & VIF & \\
\hline Revenue $\left(\mathrm{X}_{1}\right)$ & 0.781 & 1.281 & Non Multicollinearity \\
Yard Area $\left(\mathrm{X}_{2}\right)$ & 0.938 & 1.066 & Non Multicollinearity \\
Dependents $\left(\mathrm{X}_{3}\right)$ & 0.737 & 1.357 & Non Multicollinearity \\
Mother's Education $\left(\mathrm{X}_{4}\right)$ & 0.963 & 1.039 & Non Multicollinearity \\
Number of working families $\left(\mathrm{X}_{5}\right)$ & 0.795 & 1.258 & Non Multicollinearity \\
\hline
\end{tabular}

Source: SPSS data (processed), 2021

Based on the table above, it can be seen that household income variables, yard area, number of household members, education of housewives, and number of working families have tolerance values $>1$ and VIF > 10, meaning that there is no multicollinearity. So it can be concluded that there is no perfect correlation between the variables of household income, yard area, number of household members, education of housewives, and number of working families, so the multicollinearity test has been fulfilled.

\subsubsection{Heteroscedasticity Test}


Heteroscedasticity test aims to test whether in the regression model there is an inequality of variance from one observation residual to another observation. Testing the symptoms of heteroscedasticity in multiple linear regression equations can be known by the Scatterplot method. If there is a certain pattern, such as the dots that form a certain regular pattern (wavy, widened then narrowed), it indicates that heteroscedasticity has occurred. On the other hand, if there is no clear pattern, and the points spread above and below the number 0 on the $\mathrm{Y}$ axis, then there is no heteroscedasticity, so the regression model is feasible to use. The results of the Heteroscedasticity Test analysis can be seen in Figure 2 below:

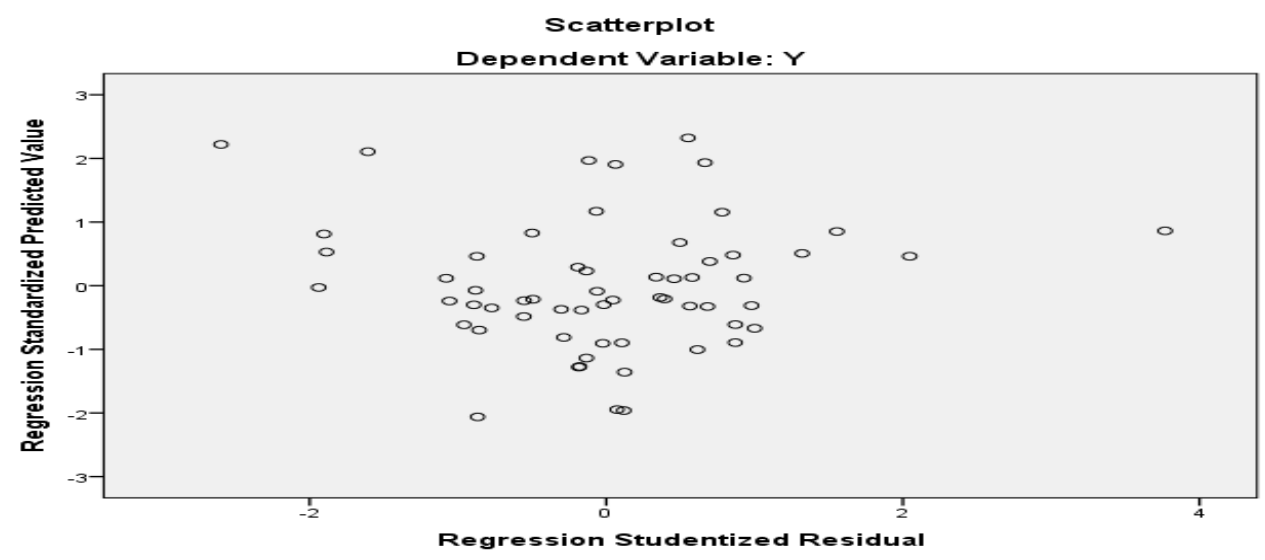

Figure 2. Scatterplot Graph

Based on figure 2 above, it can be seen that there is no heteroscedasticity because there is no clear pattern and the points spread above and below the number 0 on the $\mathrm{Y}$ axis. predicts the amount of household food expenditure that utilizes yard land in Dewantara District based on household income, yard area, number of household members, housewife education, and number of working household members.

\subsection{Statistic test}

The statistical test is intended to see the relationship and influence of independent variables, namely household income, yard area, number of household members, education of housewives, and number of working families on the dependent variable, namely household food expenditure. Based on the results of multiple linear regression analysis obtained the following results:

Table 6. The results of the analysis of the influence of income factors, yard area, number of household members, mother's education, and number of family members who work on household food expenditure

\begin{tabular}{lrrrr}
\hline \multicolumn{1}{c}{ Variable } & Coefficient & \multicolumn{1}{c}{ T count } & \multicolumn{1}{l}{ Sig } \\
\hline nnnnn Constant) & 724021.586 & 2.093 & .041 \\
Revenue (X1) & .163 & & 4.666 & .000 \\
Yard Area (X2) & -680.653 & -.363 & .718 \\
Number of household members (X3) & 161606.193 & 3.838 & .000 \\
Mother's Education (X4) & 2701.296 & .120 & .905 \\
Number of working Members (X5) & -94572.030 & -1.053 & .297 \\
\hline $\mathrm{R}=0.729$ Adjust $\mathrm{R}^{2}=0.489$ & & $\mathrm{~F}_{\text {hitung }}=12.272$ & \\
$\mathrm{R}^{2}=0.532$ & & F sig $=0.000$ & \\
\hline
\end{tabular}

Source: SPSS data (processed), 2021 


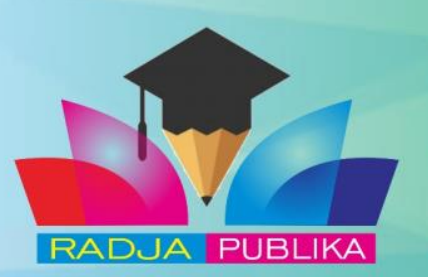

Based on table 6, the food expenditure function is obtained as follows:

\section{$Y=724021.586+0.163 X_{1}-\mathbf{- 6 8 0 . 6 5 3} X_{2}+161606.193 X_{3}+2701.296 X_{4}-94572.030 X_{5}$}

\subsubsection{Correlation Coefficient $(\mathrm{R})$}

The Correlation Coefficient (R) is intended to see how the relationship between the independent variable and the dependent variable is. From the results of the analysis it can be seen that the correlation coefficient (R) is 0.729 or $72.9 \%$, which means that the household income variable, yard area, number of household members, housewife education, and number of working members affect household expenditures that use yard land for horticultural cultivation in Dewantara District.

\subsubsection{Coefficient of Determination $\left(\mathbf{R}^{2}\right)$}

The coefficient of determination will explain how much change or variation in a variable can be explained by changes or variations in other variables. The value of the coefficient of determination can be seen from the value of $\mathrm{R}$ Square or $\mathrm{R}^{2}$. If the results obtained are closer to 0 , it means that the ability of the independent variables in explaining the variation of the dependent variable is very limited. But if the result is close to 1, it means that the independent variables provide almost all the information needed to predict the variation of the dependent variable. Based on the results of the analysis of the value of the coefficient of determination of 0.532 , it shows that income, land area of the yard, number of household members, education of housewives, and the number of working household members is able to explain household food expenditures that use their yards by $53.2 \%$, while $46.8 \%$ are explained by other variables not examined

\subsubsection{Simultaneous Testing (F Test)}

The $F$ test is a test that simultaneously sees the effect of all independent variables $\left(X_{1}\right.$, $\mathrm{X}_{2}, \mathrm{X}_{3}, \mathrm{X}_{4}$ and $\mathrm{X}_{5}$ ) which are included in the regression equation model which has a significant effect on the food expenditure variable (Y) with a significant level of 5\%. To find out income, yard area, number of household members, education of housewives, and number of household members who work for household food expenditure from the value of Sig. F. The results of the $F$ test test obtained a Sig F value of 0.000 which means $0.000<0.05$. Thus, it means collectively income, area of yard land, number of household members, education of housewives, and the number of working household members has a significant effect on household food expenditures that utilize yards with horticultural cultivation in Dewantara Sub-istrict, Aceh Utara.

\subsubsection{Partial Testing (T Test)}

Partial test (t test) was conducted to predict whether each of the independent variables, namely income, yard area, number of household members, education of housewives, and number of household members who worked had a significant or insignificant effect on household food expenditure. which utilizes yard land with horticultural cultivation in Dewantara District, Aceh Utara.

The partial t-test shows that the variables of yard area, housewife's education, and the number of household members who work have no significant effect on food expenditure as indicated by a significant value greater than alpha $>0.05$, while the variable household income and total household members have a significant effect on household food expenditure, which is indicated by a value significantly smaller than alpha, which is $<0.05$. This is the same as the research conductedPangaribuan, Husaini, and Azis (2020), that income and the number of household members have a significant effect on household expenditure, both food and non-food, while the education level of housewives has no significant effect on household expenditure.

Partially, household income variable $\left(\mathrm{X}_{1}\right)$ has a significant effect on household food expenditure $(\mathrm{Y})$ indicated by a significantly smaller value than alpha, namely $0.000<0.05$. The regression coefficient of 0.163 means that for every additional income of 1,000 IDR, then household food expenditures that use yard land with horticultural cultivation will increase by 163 IDR. This means 


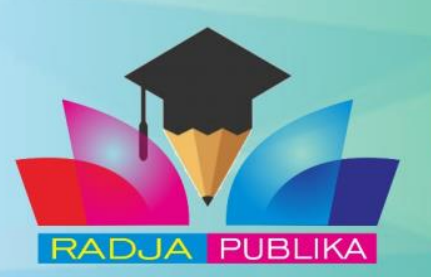

Volume 1 No. 1 (2021)

that the higher household income, the level of household food expenditure will also increase. according to Ismiasih et al. (2013), the amount of income is very influential on the allocation of household expenditures for food consumption. With the number the greater the income, the more flexible people will be in allocating their income for more diverse food consumption

Variable yard area $\left(\mathrm{X}_{2}\right)$ has no significant effect on household food expenditure (Y) which is indicated by a significant value greater than alpha, namely $0.718>0.05$. There is no effect of the variable yard area on food expenditure because the average area of yard land ownership is only $43.33 \mathrm{~m}^{2}$ and the use of yard land is not optimally occupied by housewives because the housewives who are the sample have a dual role, namely being a housewife and working in the household. other fields to meet household needs..

The variable number of household members $\left(\mathrm{X}_{3}\right)$ has a significant effect on household food expenditure (Y) which is indicated by a significantly smaller value than alpha, namely $0.000<0.05$. The coefficient value of $165,808.376$ can be interpreted that for every additional 1 person in the number of household members, household food expenditure will increase by 161,606.193 IDR. according to(Arida, Sofyan, and Fadhiela 2015), The number of household members is a characteristic related to increasing income, including household food expenditure and consumption, the more members of the household, the greater the cost, so that the expenditure and consumption are also greater.

The education variable of housewives $\left(\mathrm{X}_{4}\right)$ has no significant effect on household food expenditure $(\mathrm{Y})$, which is indicated by a significant value greater than alpha, namely $0.905>0.05$. Housewives who have higher education will be more awareto seek as much information as possible in an effort to improve the welfare of their families, including information on food knowledge and nutrition knowledge for families opinion Rachmah, Mukson, and Marzuki (2017) which states that the better the mother's nutritional knowledge, in choosing food, consideration and knowledge of the nutritional value of food will be carried out so that the nutritional needs of the household are met and the household is more prosperous. but it affects what kind of food is appropriate and safe for consumption by household members (Sadevi, Hamidah, and Permai 2020)

The variable number of working family members $\left(\mathrm{X}_{5}\right)$ has no significant effect on household food expenditure $(\mathrm{Y})$ indicated by a value significantly greater than alpha, namely $0.297>0.05$. The number of household members who work directly affects household food expenditures because household members are involved in working to increase income and the large number of dependents in the household whose needs must be met.

\section{CONCLUSION}

Based on the results of the research conducted, it can be concluded that simultaneously the variables are income $\left(\mathrm{X}_{1}\right)$, yard area $\left(\mathrm{X}_{2}\right)$, number of household members $\left(\mathrm{X}_{3}\right)$, education of housewives $\left(\mathrm{X}_{4}\right)$, and number of working household members $\left(\mathrm{X}_{5}\right)$. has a significant effect on household expenditure as indicated by the F Sig value of 0.000 which is smaller than alpha (0.05), while partially only income $\left(\mathrm{X}_{1}\right)$ and number of household members $\left(\mathrm{X}_{3}\right)$ have a significant effect on household expenditure, while The area of the yard $\left(\mathrm{X}_{2}\right)$, the education of the housewives $\left(\mathrm{X}_{4}\right)$, and the number of working household members $\left(\mathrm{X}_{5}\right)$ did not significantly affect household food expenditures using the yard with horticultural cultivation in Sawang Subdistrict, Aceh Utara.

\section{REFERENCES}

Arida, Agustina, Sofyan, and Keumala Fadhiela. 2015. "Analysis of Household Food Security Based on Proportion of Food Expenditure and Energy Consumption." Agripep 16(1): 20-34. 
https://media.neliti.com/media/publications/13198-ID-analysis-ketahanan-pangan-householdberdasarkan-proporsi-pengeluaran-pangan-d.pdf.

Arikunto S. 2013. Research Procedure A Practical Approach. Revised Edition. Publisher PT Rineka Cipta. Jakarta

Ashari, NFN, NFN Saptana, and Tri Bastuti Purwantini. 2016. "Potentials and Prospects of Using Yard Land to Support Food Security." Agro-Economic Research Forum 30 (1): 13. https://doi.org/10.21082/fae.v30n1.2012.13-30.

Dewantara Agricultural Extension Center. 2020. Plan of the 2021 Dewantara District Agricultural Extension Program. North Aceh.

Djufry, Fadjry. 2012. "Water for Food Crop Growth in Merauke Regency, Papua Water Balance Modeling To Estimate the Surplus and Water." Agricultural Informatics 21 (1): 1-9. www.litbang.pertanian.go.id/warta-ip/pdf...2012/FadjryDjufryVol21No1-2012.pdf.

Ismiasih, Slamet Hartono, Dwidjono H. Darwanto, and Jangkung H. Mulyo. 2013. "Diversification of Food Consumption at the Household Level in the Province of the Special Region of Yogyakarta (Entropy Index Approached by Food Share).” Journal of Agricultural Cultivation 9 (2): 72-78.

Martina, Nurasih Shamadiyah, and Riyandhi Praza. 2018. "The Contribution of Revenue and Consumption Cost of Soybean Farmers in Muara Batu Subdistrict Aceh Utara." Emerald Reach Proceedings Series 1: 289-94. https://doi.org/10.1108/978-1-78756-793-1-00014.

Pangaribuan, Feronika, M Husaini, and Yusuf Azis. 2020. "Household Food Consumption Expenditures On The Sustainable Food House Program (Krpl) Kecamatan Cempaka Kota Banjarbaru Household Food Expenditure on the Program of Sustainable Food House Zone (KRPL) in Cempaka Sub District Banjarbaru Municipality" 4 (September): 42-47.

Rachmah, Malinda, Mukson Mukson, and Sudiyono Marzuki. 2017. "Analysis of Factors Affecting the Share of Food Expenditure of Farmers' Households in Suruh District, Semarang Regency." Unimus Journal of Food and Nutrition 8 (14): 1-13. https://doi.org/10.26714/jpg.7.1.2017.17-27.

Ratna, Neneng, and Erni Gustiani. 2016. "The Contribution of Yard Land Utilization to the Fulfillment of Family Nutrition and Household Food Expenditure." Proceedings of the National Seminar on Agricultural Technology Innovation, no. 80:1751-56.

Reksoprayitno S. (2013). Introduction to Macroeconomics. BPFE Publisher. Jakarta

Sadevi, Ekinanda Anggita, Siti Hamidah, and Ni Made Suyastiri Yani Permai. 2020. "Analysis of Household Food Security in Kalirejo Village, Kokap District, Kulon Progo Regency.” Journal of Socio-Economic Dynamics 21 (2): 205. https://doi.org/10.31315/jdse.v21i2.3956.

Sugiono. 2017. Quantitative, Qualitative, R \& B Research Methods. CV Alphabeta Publisher. Bandung

Sumarsono, Sonny. 2009. Theoti and Public Policy ; Human Resource Economics. Yogyakarta: Graha Ilmu.

Widarjono, Agus. 2018. Introductory Econometrics and Its Applications With Guide Eviews. Fifth Edition. Yogyakarta: UPP STIM YKPN Yogyakarta. 


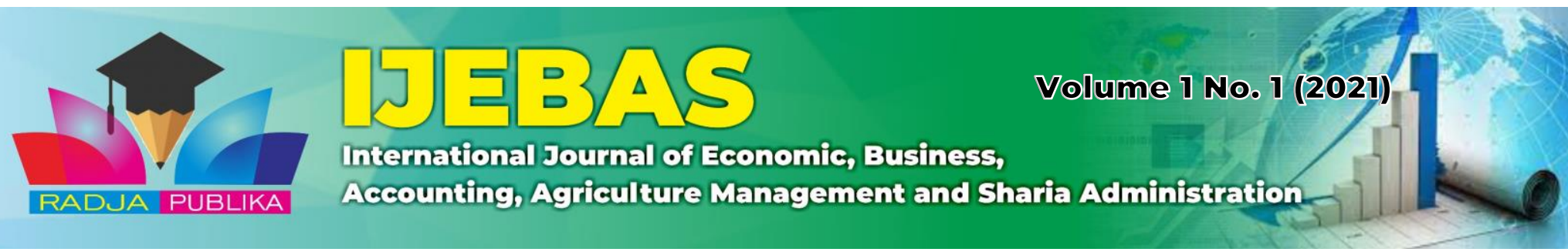

Yanti, Zella, and Murtala. 2019. "The Influence of Income, Number of Family Members and Education Level on Household Consumption in Muara Dua District, Lhokseumawe City." Indonesian Journal of Economics 8 (2): 72-81. https://ojs.unimal.ac.id/index.php/economy/article/view/972.

Yudaningrum, A. 2011. "Analysis of the Relationship between Proportion of Expenditure and Consumption of Food, Food Security and Food Security of Farmers' Households in Kulon Progo Regency." UNS - Thesis, 1-79.

Yulida, Roza. 2012. "The Contribution of Yard Farming to the Household Economy of Farmers in Kerinci District, Pelalawang Regency." Indonesian Journal of Agricultural Economics (IJAE) 3 (2): 135-54. https://ejournal.unri.ac.id/index.php/IJAE/article/view/1549/1524.

Zulkarnain. (2009). Horticulture Fundamentals. Earth Literacy Publisher. Jakarta 